\title{
Poverty And Consumption Of Fossil Energy; Case Study In Yogyakarta Special Province
}

\author{
Suripto ${ }^{1}$ \\ ${ }^{1}$ Department of Economics, Faculty of Economicsof Economics, Ahmad Dahlan University, Yogyakarta
}

\begin{abstract}
Poverty occurs because of minimum living standards. Revenues occur through the production process. This study wants to show how the consumption of fossil fuels, educational investment and physical capital in the process of economic growth affect the status of low-income families. Solow growth models will be used to explain the impact of fossil fuel consumption, education investment, and physical capital, Yogyakarta Special Province on poverty. The study was conducted by looking at the use of fossil fuels, investment of educators, and physical capital performed by households in Yogyakarta Special Province. The total sample of 3606 households obtained from raw Susenas 2013 data. Estimation model with Logit regression approach.
\end{abstract}

Keywords: Fossil Energy Consumption; Household Poverty; Logit Model; Solow Growth.

\section{Introduction}

Development success occurs when three primary objectives are achieved, namely increasing per capita income, decreasing inequality and reducing poverty, in other words, development must be able to improve people's welfare in a broad sense both economically and socially [1]. The success of the event: poverty alleviation in addition to depending on income distribution, but also the quality of human resources and the quality of energy sources Energy is the key to the production process Fuel policy regulation policies will create sustainable income for low-income families [2].

Poverty is seen from the capability approach (Capability Approach) defined as failure to achieve the ability to meet the minimum needs for a decent life [3]. The strength of this concept lies in the multidisciplinary character and focus on multidimensional well-being. The implicit policy focus is on the causes and environmental context that affect poverty. Poverty results in reduced ability to access various natural resources, both economic resources and social resources [2]. The lack of ability to access natural resources has the potential for low-income families to give birth to poor offspring. Improving the quality of human resources will also affect the income of low-income families. Policies that combine improvements in human resources and pro-poverty natural resource policies will increase revenue and reduce poverty. With the development of the quality of human resources and energy policies will be able to overcome poverty. Government policies regulating the distribution of biofuels in Malawi, Mozambique and Swaziland have a significant impact on reducing poverty and improving the quality of life of the poor [4].
Energy consumption by poor households for production needs is still dominated by the use of fossil energy, so energy use is equivalent to the growth of greenhouse gases in the atmosphere which then turns into a problem of climate change with various impacts on environmental quality. This study will look at the effects of fossil energy consumption on poverty alleviation. The purpose of this study is to see how the energy consumption patterns of the poor so that policies can be taken to reduce the negative effects of the effects of fossil energy consumption on the environment towards efforts to realize low carbon economic development.

\section{Research Model}

Model specifications are intended to reduce the household production model which will then be estimated to determine the influence of capital and expertise. The model used is the Solow growth model written [5-6]:

$Y=K^{\alpha} H^{\beta} A i L^{1-\alpha-\beta}$

$\mathrm{K}=$ physical capital (physical capital)

$\mathrm{H}=$ human capital (human capital)

$\mathrm{AiL}=$ labor productivity is augmented-labor.

Where $\alpha+\beta=1$, this means that the household production function is constant returns to scale on the three inputs used. It is assumed that households are in a perfectly competitive market, both input markets and output markets. Households accumulate capital by setting aside the aggregate income they receive. Equations of capital accumulation and accumulation of human capital are:

$\hat{K}=S K Y-\delta K$
$\hat{H}=S H Y-\delta H$ 
SK and SH are the savings rates used for substantial investment and investment in human resources, both of which are assumed to be exogenous. Both physical investment and human resource investment have the same depreciation rate of Depreciation of $\delta$ is supposed to be constant because of constant physical capital.

In the Solow Model, the most important thing is how there is a balance between an output (family income), physical capital and human capital. The balance between the production and capital occurs with the condition that there is a steady-state condition that is a condition where the investment is the same as the desired investment. In the Solow Model, all variables are measured by active workers by dividing the number of productive labor measured by AL (productivity-augmented workers). The magnitudes of variables separated by AL are called intensive variables [7]. The active production function per labor is:

$\bar{y}=\frac{K^{\alpha} H^{\beta} A L^{1-\alpha-\beta}}{\left(A L^{\alpha}\right)\left(A L^{\beta}\right)(A L)^{1-\alpha-\beta}}$

Physical capital growth per workforce is effective

$\hat{\bar{k}}=\frac{\hat{K}}{A L}-\frac{K}{(A L)^{2}}[\hat{A} L+A \hat{L}]=S K \bar{y}-\delta \bar{k}-\bar{k}(n+g)$

The growth of human capital per effective workforce

$$
\hat{\bar{k}}=S K \bar{y}-(n+g) \bar{k}
$$

To get output in steady-state conditions, equation (6), and (5) are substituted by comparison (4) obtained:

$\bar{y}^{*}=\frac{\delta K}{n+g^{*}}[K]^{\frac{\alpha}{1-\beta}} \frac{\delta H}{n+g^{*}}(H)^{\frac{\beta}{1-\alpha}}$

Equation 7 means that household income depends on physical capital and human resource capital. The impact of changes in output (family income) on is as substantial as the marginal product of physical capital: $\frac{\partial \bar{y}^{*}}{\partial K^{*}}=\frac{\delta K}{(n+g) *} \frac{\alpha}{1-\beta}$ The contribution of human resource capital to production is as significant as the marginal human capital product of $\frac{\partial \bar{y}^{*}}{\partial H^{*}}=\frac{\delta H}{(n+g) *} \frac{\beta}{1-\alpha}$

\section{Model Specifications}

Based on equation (7) formulated into an estimated research model. The research model consists of physical capital and human capital. Human capital is the main source of growth in some endogenous growth models and one of the key existence of the neoclassical model. Some studies have found evidence that skilled labor is a key determinant of economic growth. [5],[8], [9]; [10].

To cover the research objectives, the model was estimated by binary logistic regression with the binomial variable poverty status as the dependent variable. In this study logit is used with the consideration that in addition to the dependent variable being a dichotomy, this model can guarantee a probability value between 1 and 0 ; also the logit coefficient is more or less comparable to the probit coefficient when divided by 1.6. [12] Logit (Li) model for practical estimation purposes, as follows: $L y_{i}=\ln \left(\frac{p_{i}}{1-p_{i}}\right)=A_{i}+\beta_{1} K K_{i}+\beta_{2} K P_{i}+\beta_{3} R L S 15_{i}+\beta A K_{i}+\beta_{5} J P R_{i}+\beta_{6} B P_{i}$ $+\beta_{7} B P N_{i}+\beta_{8} B P P 2_{i}+\beta_{9} B B A+\beta_{10} L T K+\beta_{11} L P G+\beta_{12} K M T+\beta_{13} B B M+\varepsilon i \ldots \ldots \ldots . .(8)$

Lyi is the probability of exit 1 (for needy families), the poverty status in question is absolute poverty, the household is said to be poor if the income obtained cannot meet its minimum needs. In this study, it was supposed to be poor if the household per capita expenditure below the D.I.Yogyakarta poverty line in 2013 was Rp303,843 per capita per month [11]. The independent variable (Xij) consists of:

Table 1. Independent Variables

\begin{tabular}{|c|c|}
\hline Name & Description variable \\
\hline & Variable Measuring Human CapitalVariable \\
\hline KK & $\begin{array}{l}\text { Variable Calorie Consumption is the amount of fat of } \\
\text { processed food consumed per person per day in Kcal } \\
\text { units. Finished food consists of } 28 \text { commodities of } \\
\text { processed food consumed by households. }\end{array}$ \\
\hline KP & $\begin{array}{l}\text { Variable Protein Consumption is the amount of protein } \\
\text { consumed per person per gram per day. The food } \\
\text { consumed consists of food and processed food. Finished } \\
\text { food consists of } 28 \text { commodities. finished food } \\
\text { consumed by households consists of } 180 \text { products of } \\
\text { raw food consumed by households }\end{array}$ \\
\hline RLS & $\begin{array}{l}\text { Variable RLS Average School Duration is the average } \\
\text { number of years taken by all household members aged } \\
15 \text { years and over informal education, which is counted } \\
\text { to the highest level of education completed or the } \\
\text { highest grade/level ever occupied }\end{array}$ \\
\hline $\mathrm{AK}$ & $\begin{array}{l}\text { Health Variables are health insurance covering } \\
\text { Jamkesmas, Jamkesda, Jampersal, This variable is a } \\
\text { dummy variable. }\end{array}$ \\
\hline JPR & $\begin{array}{l}\text { Variable Food Security is the average number of Raskin } \\
\text { purchased/received in kilograms per month. }\end{array}$ \\
\hline $\mathrm{BP}$ & $\begin{array}{l}\text { Educational Scholarship Variables Education } \\
\text { scholarships are educational scholarships obtained by } \\
\text { households in universities. This variable is a dummy } \\
\text { variable, worth } 1 \text { if the family has education insurance } \\
\text { and is worth } 0 \text { if education insurance is not guaranteed. }\end{array}$ \\
\hline BPN & $\begin{array}{l}\text { Variable Education Cost is the cost of non-formal } \\
\text { education Course fees are the expenses incurred for } \\
\text { consumption of the cost of course fees for all household } \\
\text { members for a month, in rupiah. }\end{array}$ \\
\hline \multirow[t]{2}{*}{ BPP } & $\begin{array}{l}\text { Variable Disease Prevention is a disease prevention fee } \\
\text { / Medical Check Up per month. }\end{array}$ \\
\hline & Variable Measuring Physical Capital \\
\hline BBB & $\begin{array}{l}\text { Non-oil Fuel Consumption Variables are the } \\
\text { consumption of fuel from charcoal, coal, and briquettes } \\
\text { in the last month with a unit of thousand rupiah }\end{array}$ \\
\hline LK & $\begin{array}{l}\text { Variable Electricity Consumption is the use of } \\
\text { electricity for the last month with a group of thousand } \\
\text { rupiahs. }\end{array}$ \\
\hline LPG & $\begin{array}{l}\text { Liquefied petroleum gas LPG L P G in the last month } \\
\text { with a unit of thousand rupiahs. }\end{array}$ \\
\hline KMT & $\begin{array}{l}\text { Variable of kerosene consumption in the last month } \\
\text { with a unit of thousand rupiah }\end{array}$ \\
\hline BBM & $\begin{array}{l}\text { Variable Fuel consumption for generator engines in } \\
\text { the form of fuel oil (BBM) consists of; gasoline, } \\
\text { diesel, kerosene in the last month unit of thousands } \\
\text { of rupiah. }\end{array}$ \\
\hline
\end{tabular}

\section{Data Analysis}

Statistical analysis for the equation (8) model starts with the estimation of the logit model using Maximum 
Likelihood Estimator (MLE). The next step is to test the model individually (partial) using the test statistic Z. H0 is rejected if the $\mathrm{p}$-value $\angle \mathrm{BBBB}$ significance level (ie 0.05 or 0.10 ). Test the overall model (simultaneous) with the likelihood ratio (LR) test statistic. LR distributes chisquare (X2) with degrees of freedom as many as independent variables do not include constants. The condition for rejecting the null hypothesis is that if the $\mathrm{p}$ value is $<0.05$ or 0.10 we reject $\mathrm{H} 0$. Test the goodness of the regression line (goodness of fit) with McFadden R2 (R2McF) with values ranging from 0 to 1 .

The final step is the model interpretation. The interpretation of the logit model will be distinguished according to the type of variable, namely categorical and variable variables. Parameter interpretation category variable is done by comparing the unique value of one of the values of the variable with the unusual amount of the other value (reference).

\section{Results And Discussion}

The data used in this study is secondary data with the primary data coming from the Susenas raw data of the Special Province of Yogyakarta in 2013. Susenas is a survey to collect social demographic data which includes data on education, health/nutrition, housing, socioeconomic, travel and the opinions of the community. The Susenas sample in 2013 consisted of 3,606 households with the number of household members (individuals) 11,825 people.

The estimation results of the logit model of poverty determinant using MLE in 2013 are as follows:

Table 2. Estimation of MLE Method Parameters for Test Logit Model of Poverty Status in Yogyakarta Special Region Province

\begin{tabular}{|l|l|l|l|l|}
\hline \multicolumn{5}{|l|}{ Dependent Variable: Y } \\
\hline \multicolumn{4}{|l|}{ Included observations: 3606} \\
\hline Variable & Coefficient & $\begin{array}{l}\text { Z- } \\
\text { Statistic }\end{array}$ & $\begin{array}{l}\text { Odds } \\
\text { Rasio }\end{array}$ & $\begin{array}{l}\% \\
\text { Influence }\end{array}$ \\
\hline C & $-0,757771$ & $-4,12381$ & 0 & $-53,128$ \\
\hline KK* & $-0,000354$ & $-3,56507$ & 0,04 & $-0,0353$ \\
\hline KP & $-0,001452$ & $-0,65295$ & 51,38 & $-0,1946$ \\
\hline RLS & $-0,002181$ & $-0,20315$ & 83,9 & $-0,2178$ \\
\hline AK** & $-0,210846$ & $-2,37515$ & 1,75 & $-19,01$ \\
\hline JPR** & $-0,004073$ & $-2,39465$ & 1,66 & $-0,406$ \\
\hline BP* & $-0,276672$ & $-2,67574$ & 0,75 & $-24,169$ \\
\hline BPN & $-4,82 E-06$ & $-1,59957$ & 10,97 & $-0,0048$ \\
\hline BPP & $-1,12 \mathrm{E}-05$ & $-0,67749$ & 49,81 & $-0,001$ \\
\hline BBA & 0,092762 & 0,780318 & 43,52 & 9,720 \\
\hline LK* & 0,921269 & 5,963152 & 0 & 151,24 \\
\hline KMT & 0,106075 & 0,791289 & 42,88 & 11,190 \\
\hline BBM & 0,3586 & 2,226058 & 2,6 & 43,132 \\
\hline LPG* & $-0,497246$ & $-3,39816$ & 0,07 & $-39,17$ \\
\hline McFadden R-squared : 0,536267 & & \\
\hline LR statistic (13 df) : 214,7123 & & \\
\hline
\end{tabular}

Source: Data is processed from the 2013 DIY Susenas raw data
Test the determinant coefficients individually in table 2 by comparing the $\mathrm{Z}$ values with $\mathrm{Z}$ tables, namely for the level of significance () of 0.05 or 0.10 , respectively 1.64 or 1.28 , indicating that the variables of Calorie Consumption (KK), Insurance Health (AK), Food Security (JPR), Education Scholarship (BP), Electricity Consumption (LK) and LPG Consumption are statistically significant and significant at 5 percent significance level on household poverty status in Yogyakarta Special Province. School duration variables (KP), disease prevention costs (BPP), charcoal fuel, coal (BBA), kerosene consumption (BM T) and kerosene consumption (BBM) have no statistical effect.

Simultaneous test Logit regression model shows the statistical LR value of 214.7123, while the table value at the 0.05 significance level is 32.67 , this means the null hypothesis is rejected and accepts the alternative theory, suggesting that statistically the independent variables together can explain the variable of poverty in Yogyakarta Special Province.

The goodness of fit test as contained in table 2. has a coefficient of determination that is $\mathrm{R} 2 \mathrm{McF}$ of 0.536267 ; this shows the variables in the model can explain 53.62 percent variation in poverty status in the Special Province of Yogyakarta in 2013.

The preferred economic analysis looks at the signs attached to the variables observed. Signs attached to the variable indicate the suitability of the expected signs in theory or based on research that has a positive impact on poverty is the consumption of charcoal fuel, briquettes, coal, electricity consumption, kerosene consumption and consumption of fuel oil (gasoline, diesel). Energy consumption variables that have a positive impact mean that this variable contributes to increased poverty. The addition of energy consumption is not related to an increase in household productivity, suggesting that energy consumption is not associated with the income-producing production

Energy consumption which has a negative impact on the poor status of households is the consumption of LPG, and this means that households that consume more LPG will experience a decrease in the probability of entering the poor category. LPG consumption by households is related to increased income. It can be assumed that LPG helps increase family income.

The variable human capital has a negative influence on the poor status of families in the province of DIY, meaning that all investments in human capital have an impact on labor productivity. Increased human capital will reduce the probability of households becoming poor. The most significant influence of human capital on the decline of poor status is education and health insurance scholarships, and this shows that the income of the low-income class of the population $(20 \%$ of the lowest income population) depends on a feeling of certainty of obtaining a guarantee of health and education.

Variable physical capital that is proxied by the consumption of oil and gas and non-oil and gas fuels has various influences. The positive and most significant impact on improving the poor status of households is electricity consumption. Increased electricity consumption 
causes households to have a rising probability of entering the poor category. LPG consumption ranks second largest after electricity consumption. LPG consumption has a negative impact, meaning that more LPG consumption will make households have a lower poor probability.

\section{Conclusion}

Based on the results of this study it can be concluded that:

1. Energy consumption variables that negatively affect the poor status of households in the Province in Yogyakarta Special Region are LPG consumption.

2. Energy consumption variables that have a positive effect on the poverty level of households in the Province of Yogyakarta Special Region are electricity consumption, kerosene consumption, coal consumption and charcoal

3. All variables of human capital have a negative influence on the poverty status of households in the Province of Yogyakarta Special Region.

4. The energy consumption variable that has the most significant impact on the poor state of households in the Province of Yogyakarta Special Region is that LPG consumption follows electricity consumption.

5. The most significant human capital variable affecting the status of poor households in the Province of Yogyakarta Special Region is education scholarships, followed by use of health insurance.

6. The policy for realizing Low Carbon National Development can be done by providing electricity and gas fuel subsidies (LPG) in poor households, while developing cheap energy sources that are of the right kind of chemistry to realize Low Carbon Development.

\section{References}

1. Smith, S. C., \& Todaro, M. P. The Developed and Developing World Income (2012).

2. Nkolo, J. C., Motel, P. C., \& Guegang, C. Incomegenerating Effects of Biofuel Policies: A Meta- analysis of the CGE Literature. Ecological Economics, 147(January), 230-242. (2018).

3. Xu, K., \& Osberg, L. On the Sen's Approach to Poverty Measures and Recent Developments. China Economic Quarterly, (June), 1-34 (2001).

4. Mudombi, S., Von Maltitz, G. P., Gasparatos, A., Romeu-Dalmau, C., Johnson, F. X., Jumbe, C., ... Willis, K. J. Multi-dimensional poverty effects around operational biofuel projects in Malawi, Mozambique, and Swaziland. Biomass and Bioenergy, 1-14 (2016).

5. Slobodyan, S. Indeterminacy and stability in a modified Romer model. Journal of Macroeconomics, 29(1), 169-177. (2007).

6. Arnold, J., Bassanini, A., \& Scarpetta, S. Solow or Lucas, Testing speed of convergence on a panel of $O E C D$ countries. Research in Economics, 65(2), 110-123. (2011)

7. Barro, R, Macroeconomics: A Modern Approach, 513 Retrieved from http://books.google.co.mz/books?id=g_y0eJLbD A4C, (2007).

8. Messinis, G., \& Ahmed, A. D. Cognitive skills, innovation, and technology diffusion. Economic Modelling, $\quad 30(1), \quad 565-578$. https://doi.org/10.1016/j.econmod.2012.10.002 (2013).

9. Pradhan, M., Suryahadi, A., Sumarto, S., \& Pritchett, L. Measurements of Poverty in Indonesia 1999 and Beyond, (September), 50 (2000).

10. Dias, J., \& Tebaldi, E. Institutions, Human Capital and Growth: The Long-Run Institutional Mechanism. CODE 2011 - Anais Do I Circuito de Debates Acadêmicos, 1-21 (2012).

11. BPS. Daerah Istimewa Yogyakarta Dalam Angka 2015. Badan Pusat Statistik D.I. Yogyakarta, 53(9), 1689-1699. (2015).

12. Gujarati, D. Basic Econometrics.pdf. (n.d.). (2004) 